\title{
The complex early life history of a marine estuarine-opportunist fish species, Solea turbynei (Soleidae) from temperate South Africa
}

\author{
Nadine A. Strydom ${ }^{1}$, Crystal J. Coetzer ${ }^{1}$, Paula Pattrick ${ }^{1,2}$ \\ ${ }^{1}$ Department of Zoology, P.O. Box 77000, Nelson Mandela Metropolitan University, Port Elizabeth, 6031, South Africa. \\ E-mail: nadine.strydom@nmmu.ac.za \\ ${ }^{2}$ Current address: South African Institute for Aquatic Biodiversity (SAIAB), Private Bag 1015, Grahamstown 6140, \\ South Africa.
}

\begin{abstract}
Summary: The early life history stages and ecology of Solea turbynei, a marine estuarine-opportunist species, is described from nursery areas in Algoa Bay, South Africa. Early life history stages were collected over multiple years from known nursery habitats using plankton, fyke and larval seine nets. The larvae are described using morphometric measurements, meristic counts and pigmentation based on 29 individuals. Solea turbynei is differentiated from other Soleidae by the small size at flexion (3-4 mm), low myomere count and presence of two characteristic blotches of pigment on the dorsal fin. This species has a unique early life history strategy in that the larvae progressively span nearshore, surf zone and estuarine habitats with ontogeny. Abundance of preflexion stages peaks in summer in nearshore waters, indicative of peak spawning period but preflexion larvae are present throughout the year, indicating protracted spawning by adults. At flexion stage, larvae utilize surf zones where metamorphosis and settlement takes place. Early juveniles migrate into the sandy lower reaches of estuaries, after which fish take up residency to adulthood. Warm water is important for larval growth and survival in the nearshore, while turbidity shows a positive relationship with recruitment into estuarine nurseries.
\end{abstract}

Keywords: Pleuronectiformes; ichthyology; developmental stage; coastal habitat use; Solea bleekeri.

La compleja historia natural de las fases tempranas del pez marino y ocasional estuárico Solea turbynei (Soleidae) en una región templada de Sudáfrica

Resumen: En este estudio describimos la ecología y fases de desarrollo temprano de Solea turbynei, una especie marina y ocasionalmente estuárica, en áreas de cría en Algoa Bay, Sudáfrica. Se recogieron larvas durante años en áreas conocidas de cría usando redes de plancton, trampas mareales y redes de cerco. Las larvas se describen a partir de medidas morfométricas, número de miómeros y pigmentación de 29 individuos. Solea turbynei se diferencia de otros Soleidae por su pequeño tamaño en la fase deflexión (3-4 mm), su bajo número de miómeros y la presencia de dos manchas características en la aleta dorsal. Esta especie presenta una estrategia vital única en la cual las larvas alcanzan progresivamente la zona costera, la zona de rompiente y los hábitats estuarinos a lo largo de su desarrollo. La abundancia de las fases de pre-flexión en aguas costeras alcanza su pico en verano, indicando un periodo de máxima reproducción, pero estas larvas en pre-flexión se encuentran durante todo el año, lo cual es indicativo de un alargado periodo de reproducción. En la fase de flexión las larvas realizan la metamorfosis y el asentamiento en las zonas de rompiente. Los primeros estados juveniles migran hacia las zonas bajas de fondos arenosos de los estuarios, para después convertirse en adultos. Una temperatura cálida del agua es importante para el crecimiento y la supervivencia de las larvas en la zona costera, mientras que la turbidez muestra una relación positiva con el reclutamiento en las zonas de cría de los estuarios.

Palabras clave: Pleuronectiformes; ictiología; estados de desarrollo; uso de hábitats costeros; Solea bleekeri.

Citation/Como citar este artículo: Strydom N.A., Coetzer C.J., Pattrick P. 2015. The complex early life history of a marine estuarine-opportunist fish species, Solea turbynei (Soleidae) from temperate South Africa. Sci. Mar. 79(2): 169-178. doi: http://dx.doi.org/10.3989/scimar.04193.18A

Editor: M.P. Olivar.

Received: December 5, 2014. Accepted: March 24, 2015. Published: May 25, 2015.

Copyright: () 2015 CSIC. This is an open-access article distributed under the Creative Commons Attribution-Non Commercial Lisence (by-nc) Spain 3.0. 


\section{INTRODUCTION}

The Soleidae (Pleuronectiformes) are benthic, dextral flatfishes occurring commonly in coastal waters of the Northern and Southern hemispheres (Smith and Heemstra 1995, Nelson 2006). Soles are pelagic spawners, some with potentially complex spawning migrations and early life history strategies. Despite the abundance of soleids in coastal habitats, the ecology and description of early life history stages is not fully elucidated for southern African species. The larval stages of nine of the 56 species of Pleuronectiformes have been described from southern African waters (Wood 2000, Thompson et al. 2007) but few studies have shed light on the complexity of the early life history of these species. Solea turbynei (formerly known as Solea bleekeri) is a case in point in which the larvae, in various stages of development, occur in a variety of coastal habitat types yet the ontogeny and ecology has not been described.

Solea bleekeri Boulenger, 1898 was replaced by Solea turbynei Gilchrist, 1904 as the former name was found to be a junior synonym of Pegusa nasuta. After redescription, all representatives known as $S$. bleekeri and Solea simonensis von Bonde, 1922 were classified as Solea turbynei (Vachon et al. 2005). The species is a common endemic inhabitant of estuarine and coastal areas ranging from Tanzania, on the east coast of Africa, to the Oliphants Estuary on the Western Cape coast of South Africa (Smith and Heemstra 1995, MontoyaMaya and Strydom 2009). Solea turbynei is classified as a marine estuarine-opportunist species that usually spawns at sea, with the juveniles occurring in estuaries but also at sea (Whitfield 1998, Potter et al. 2013). Adults are known to prefer turbid waters, particularly over muddy substrates in estuaries (Cyrus and Blaber 1987, Richardson et al. 2006), where they feed mainly on the siphon tips of the bivalve Solen spp. but also on amphipods and tanaids (Heemstra and Heemstra 2004). There is evidence for seaward migration for spawning by $S$. turbynei, from winter through to mid-summer on the subtropical coast of South Africa (Cyrus and Blaber 1987). Completion of metamorphosis of $S$. turbynei is thought to occur approximately two months after hatching (Cyrus and Martin 1991). Larvae are known to occur in the nearshore (Beckley 1986; Pattrick and Strydom 2008), surf zones (Strydom 2003, Pattrick and Strydom 2014a) and estuaries (MelvilleSmith and Baird 1980, Kruger and Strydom 2010). The reported complexities of the reproductive biology of Solea turbynei (Cyrus 1991, Van Schie and de Boer 2003) and the occurrence of early life history stages in nearshore, surf and estuarine waters warrants a more detailed investigation into the early life history strategy of this species. Algoa Bay provided the ideal study site to expand and synthesize knowledge of the species in order to understand the early life history strategy. The study area is subject to longer, dedicated ichthyoplankton research across a range of habitat types where larvae are known to occur, thereby enabling a better understanding of complex patterns of occurrence with ontogeny.
The aim of this paper was to describe the larval development and better understand the early life history strategy of the species by assessing patterns of occurrence of larvae at an ontogenetic stage in the various fish nursery habitats sampled.

\section{MATERIALS AND METHODS}

\section{Study area}

Algoa Bay is a wide, shallow ( $<70 \mathrm{~m}$ deep), logspiral bay approximately $80 \mathrm{~km}$ in length located in the Indian Ocean on the southeast coast of South Africa (Schumann et al. 2005, Goschen and Schumann 2011) (Fig. 1). The Bay is influenced by nearshore oceanographic features as well as the warm Agulhas Current flowing south westwards along the edge of the continental shelf about $50 \mathrm{~km}$ offshore of the Bay (Goschen and Schumann 1994). This current dominates large-scale oceanography in the area as well as the presence of shear-edge eddies and plumes which penetrate over the shelf and are driven into the Bay. On occasion, these warm water intrusions provide significant changes to nearshore oceanography and biological interactions (Goschen and Schumann 1994, Pattrick and Strydom 2014b). The climate in the region is warm temperate, with autumn and spring peaks in rainfall and nearshore sea-surface temperatures ranging from $11^{\circ} \mathrm{C}$ to $24^{\circ} \mathrm{C}$ (Whitfield 1998 , Beckley 1986). The prevailing wind directions in Algoa Bay are parallel to the seascape. The predominant west-southwesterly and east-northeasterly winds drive the ocean currents within the bay (Goschen and Schumann 2011), with the resulting swell creating onshore and alongshore transport of water (Schumann et al. 2005). Nearshore currents are largely driven by seasonal wind events in the shallow coastal waters of the bay (Pattrick et al. 2013). Easterly winds induce upwelling on the southern side of the two headlands of the bay, at Cape Recife and Cape Padrone (Goschen and Schumann 1995, 2011). These upwelling events contribute vital nutrients to the coastal environment for primary and secondary production (Schumann et al. 2005, Pattrick and Strydom 2014b). Two large permanently open estuaries, namely the Sundays and the Swartkops, open into the western half of the Bay (Fig. 1).

\section{Field sampling and laboratory analysis}

The early life history stages of Solea turbynei were collected in Algoa Bay as part of a larger ichthyoplankton research programme that sampled over multiple years and all seasons using plankton nets, larval seine or fyke nets, depending on the habitat sampled. Mesh size for all gear types ranged from 500 to 1000 $\mu \mathrm{m}$. The samples were fixed in $10 \%$ formalin and later preserved in $70 \%$ ethanol. Nearshore samples were collected from 2005 to 2007 at three sites (SN1 - SN4) along $\sim 5$ and $15 \mathrm{~m}$ depth contours (Fig. 1). Nearshore data were supplemented with sampling on the $30 \mathrm{~m}$ depth contour at six sites (N1-N6) between August 2010 and July 2012. Samples were collected with a 




Fig. 1. - The geographic position of Algoa Bay, South Africa, showing location of sampling stations between Cape Recife and Woody Cape used to assess nursery area use by early developmental stages of Solea turbynei. Nearshore: N1 - 6 (30 m depth contour), SN 1-3 ( 5 m and $\sim 15 \mathrm{~m}$ depth contours); Surf zone: L1 - 5 (leeward side) and W1 - 5 (windward side); estuaries: Swartkops (E1) and Sundays (E2).

$75 \mathrm{~cm}$ ring net or a $75 \mathrm{~cm}$ Bongo net with a mesh aperture of $500 \mu \mathrm{m}$ using stepped oblique tows. Catches were expressed as density per $100 \mathrm{~m}^{3}$. Samples were collected from surf zones in Algoa Bay from December 2010 to October 2012. A modified beach seine net measuring $4.5 \mathrm{~m}$ wide and $1.5 \mathrm{~m}$ in height with a mesh aperture of $500 \mu \mathrm{m}$ was used. The net was hauled by two people, over a distance of $25 \mathrm{~m}$ parallel to shore. Catches were expressed as catch per unit effort (CPUE). The permanently open mouth region of the Swartkops and Sundays estuaries was sampled from December 2010 to October 2012. Samples were collected on ebb and flood tides over a 24-h period on each occasion. Four fyke nets were anchored in the estuary margin to sample each tide state over a set time period. The double-winged, 1-mm mesh aperture net was stabilized with 1.9-m-long iron bars on each end of the net. Two nets faced downstream and two nets faced upstream on each sampling occasion. Catches were emptied after each turn of the tide. Catches were expressed as CPUE. Water temperature $\left({ }^{\circ} \mathrm{C}\right)$, salinity and turbidity (NTU) were recorded at each sampling site on each sampling occasion using a Yellow Springs Instrument 6600 multi-parameter water quality meter.

In the laboratory, all specimens were identified as Solea turbynei, using the 'Series method' based on adult fin ray and vertebrae counts in conjunction with morphometric, meristic and pigmentation characteristics of larvae. The larval stage is defined as the period after hatching to the attainment of a full fin ray complement and no longer possesses temporary specializations for pelagic life (Neira et al. 1998). A Leica M80 stereomicroscope fitted with an eyepiece micrometer was used for measuring specimens $<10 \mathrm{~mm}$ in size. Vernier callipers were used for larger specimens. All specimens were measured three times to reduce error. Specimens were measured to the nearest $0.1 \mathrm{~mm}$ according to Neira et al. (1998). The notochord length (NL) was measured in preflexion and flexion stages while standard length (SL) was measured in postflexion, settlement and juvenile stages. These measurements are hereafter referred to as body length (BL). Head length (HL) was measured from the snout to the posterior region of the operculum and body depth (BD) was measured at the base of the pectoral fin and excluded the finfolds. Preanal length (PAL) was measured from the snout to the posterior end of the anus. All measurements were expressed as a percentage of BL, categorizing the overall body shape, head size and gut size of the species. The larval characteristics were described through the developmental series and comprise changes in pigmentation, gut morphology, air bladder, eyes, mouth, teeth and the sequence of development of fins and vertebrae. Specimens that best represented the various developmental end-points were selected and drawn using a Leica M80 mounted Camera Lucida. Larvae were also cleared and double stained to aid meristic counts. Representative specimens used in this description were deposited in the National Fish Collection at the South African Institute for Aquatic Biodiversity, Grahamstown (Ref: SAIAB 200511). 


\section{Data analysis}

Data were tested for normality and homogeneity of variance using the Shapiro Wilks and Levene test, respectively, and density and CPUE data did not conform to parametric test assumptions. Non-parametric analyses were performed using Statistica 11 (2012). A significance level of $\mathrm{P} \leq 0.05$ was used for all tests. A Kruskal-Wallis ANOVA $(\mathrm{H})$ by ranks was used to test for seasonal differences in catch in the nearshore, surf zone and estuaries sampled. Each habitat was treated separately as data were collected using different methods. A Mann-Whitney U-test (U) was used to test for catch difference between windward and leeward surf zones in Algoa Bay. A multiple linear stepwise regression was used to investigate the relationship between physico-chemical variables and larval catches in each nursery habitat.

\section{RESULTS}

\section{Larval description}

The description of the larval stages of Solea turbynei was obtained from 29 wild-caught larvae ranging from preflexion to juvenile stages. Preflexion larvae ranged from 2.6 to $3.0 \mathrm{~mm} \mathrm{BL}$ (Fig. 2A). Flexion occured between 3.0 and $4.0 \mathrm{~mm}$ (Fig. 2 B). Postflexion larvae ranged in length from 4.3 to $4.5 \mathrm{~mm}$ BL (Fig. 2C). Only one near-settlement stage larva (4.8 mm BL) was examined and was in the early stage of metamorphosis (Fig. 2D). A juvenile, collected with fyke nets, is also shown (Fig. 2E).

\section{Morphology}

The body shape of larvae was classified as moderate (BD 32\%-38\%) throughout development (Fig. 2A-D). The BD increased from the preflexion to the flexion stage $(38 \%)$ and then decreased with the onset of metamorphosis $(32 \%)$ in the late postflexion stage (>4.5 mm BL) (Table 1). Larvae have a moderate-sized head (HL 24\%-30\% BL) throughout development. The hindbrain is located between two distinct dorso-anterior protrusions on the forehead that are prominent in larvae $<4 \mathrm{~mm}$ BL (Fig. 2A, B) but their prominence decreases by $4.3 \mathrm{~mm}$ BL. The eye is prominent throughout larval development. The mouth does not reach the rear of the eye until the postflexion stage (Fig. 2C). Thereafter, it decreases in size as the head develops. The mouth in the juvenile stage is lower and the snout slightly hooked (Fig. 2E). Bluntly pointed teeth occur on the dentary of preflexion larvae at $3.0 \mathrm{~mm}$ BL and on the premaxilla during flexion at $3.1 \mathrm{~mm} \mathrm{BL}$. The gut is moderate in size and fully coiled throughout development (PAL $33 \%-44 \%)$. The gas bladder is visible throughout larval development and is located above the large gut.

\section{Fin meristics and sequence of formation}

No fin spines or extraordinary large rays are present in the fins of Solea turbynei larvae during development. The visible dorsal fin count at flexion (3.0-4.0 $\mathrm{mm} \mathrm{BL}$ ) ranged from 40 to 64 fin rays. Dorsal fin rays increased to $58-65$ at $\sim 4.5 \mathrm{~mm}$ BL. The anal fin rays appear simultaneously with the dorsal fin numbering 30-49 during the flexion stage and 43-49 during the postflexion stage. Postflexion larvae $>4.3 \mathrm{~mm}$ BL possess the dorsal and anal fin ray complement for adults (D 64-74 and A 46-59). The last dorsal and anal fin ray is joined to the base of the caudal fin by a basal membrane in the settlement stage $(4.8 \mathrm{~mm}$ BL) (Fig. 2D). Ossification of the pectoral fin occurs after settlement, when $5+5$ rays become evident on the blind and ocular side. The caudal fin count matches those of the adult $(\mathrm{C}=20)$ by $4.8 \mathrm{~mm} \mathrm{BL}$ in the settlement stage (Fig. 2D). The sequence of fin formation shows that preflexion larvae possess a noticeable median fin fold until $3.0 \mathrm{~mm} \mathrm{BL}$. The very large transparent pectoral fin buds occur from hatching and persist until the settlement stage (Fig. 2A-D), after which ossification occurs. The dorsal and anal fin anlagen appear simultaneously at $\sim 3 \mathrm{~mm}$ BL. Caudal fin formation also starts at flexion $(3.0 \mathrm{~mm} \mathrm{BL})$. The pelvic fin is not visible until the settlement stage (4.8 mm BL, Fig. 2D).

\section{Myomeres and vertebrae}

Myomeres were difficult to count on small larvae. From the flexion stage, myomeres ranged from 9 to $10+22-24$, including the urostyle. Cleared and stained specimens showed a vertebral count ranging from 32 to 34 , within the range for adults (32 to 37 ) in southern Africa (Smith and Heemstra 1995).

Table 1. - Morphometric measurements and body proportions for larval developmental stages of Solea turbynei (HL, head length; ED, eye diameter; BD, body depth; PAL, pre-anal length) relative to body length (BL).

\begin{tabular}{|c|c|c|c|c|c|}
\hline $\mathrm{n}$ & $\begin{array}{c}\text { Preflexion } \\
4\end{array}$ & $\begin{array}{l}\text { Flexion } \\
16\end{array}$ & $\begin{array}{c}\text { Postflexion } \\
5\end{array}$ & $\begin{array}{c}\text { Settlement } \\
1\end{array}$ & $\begin{array}{c}\text { Juvenile } \\
2\end{array}$ \\
\hline \multicolumn{6}{|c|}{ Morphometric measurments mm Mean ( \pm Standard Deviation) } \\
\hline $\mathrm{BL}$ & $2.8(0.2)$ & $3.4(0.3)$ & $4.4(0.1)$ & 4.8 & $22.8(1.2)$ \\
\hline HL & $0.7(0.1)$ & $1.1(0.2)$ & $1.1(0.1)$ & 1.3 & $4.9(0.1)$ \\
\hline ED & $0.2(0.0)$ & $0.2(0.0)$ & $0.3(0.0)$ & 0.25 & $0.9(0.1)$ \\
\hline $\mathrm{BD}$ & $1.0(0.1)$ & $1.3(0.2)$ & $1.42(0.1)$ & 1.6 & $6.4(0.5)$ \\
\hline PAL & $1.1(0.1)$ & $1.5(0.2)$ & $1.54(0.0)$ & 1.6 & $6.5(2.3)$ \\
\hline \multicolumn{6}{|c|}{ Body proportions (\%) } \\
\hline $\mathrm{HL}(\% \mathrm{BL})$ & $24.0(1.3)$ & $31.0(2.8)$ & $26.0(0.7)$ & 27.0 & $21.5(0.5)$ \\
\hline $\mathrm{ED}(\% \mathrm{BL})$ & $6.6(0.3)$ & $7.0(0.5)$ & $5.7(0.1)$ & 5.2 & $4.0(0.8)$ \\
\hline $\mathrm{BD}(\% \mathrm{BL})$ & $34.0(3.0)$ & $38.1(3.7)$ & $32.4(1.5)$ & 32.3 & $28.2(3.7)$ \\
\hline PAL (\% BL) & $39.5(3.3)$ & $44.0(3.7)$ & $35.2(1.0)$ & 33.3 & $28.3(8.8)$ \\
\hline
\end{tabular}


(A) $2.8 \mathrm{~mm} \mathrm{BL}$
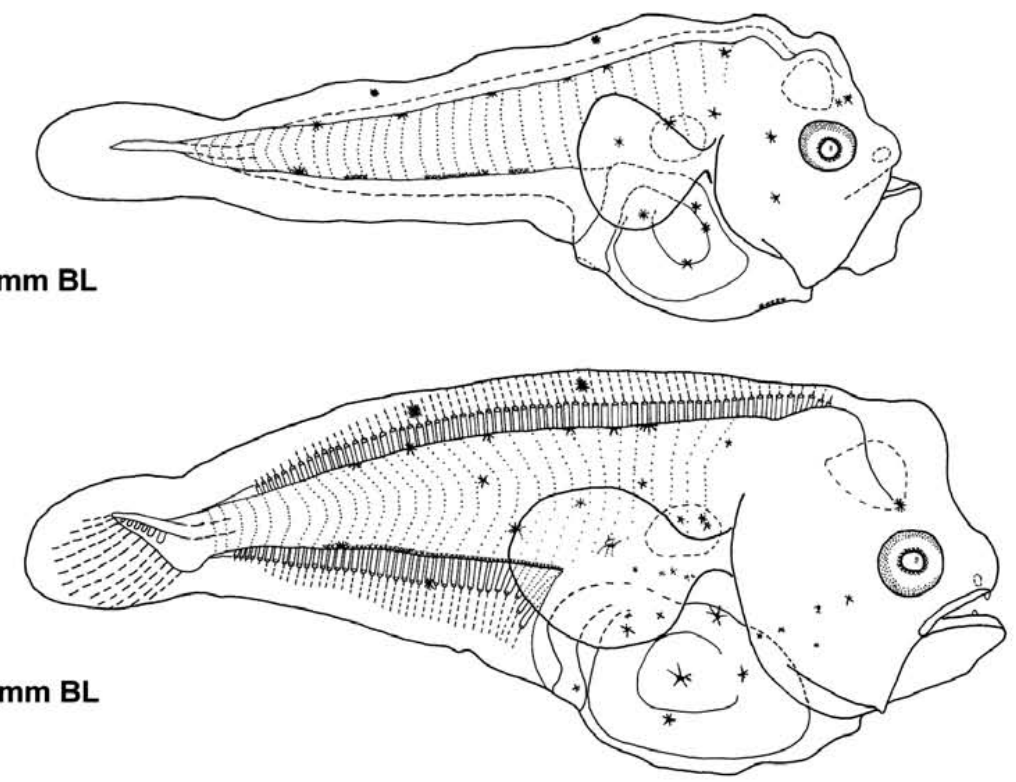

(B) $3.0 \mathrm{~mm} \mathrm{BL}$

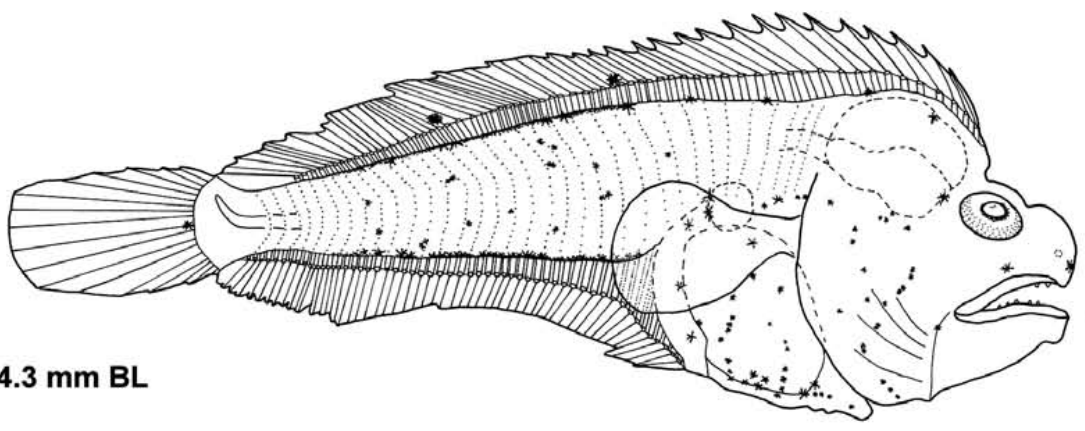

(C) $4.3 \mathrm{~mm} \mathrm{BL}$
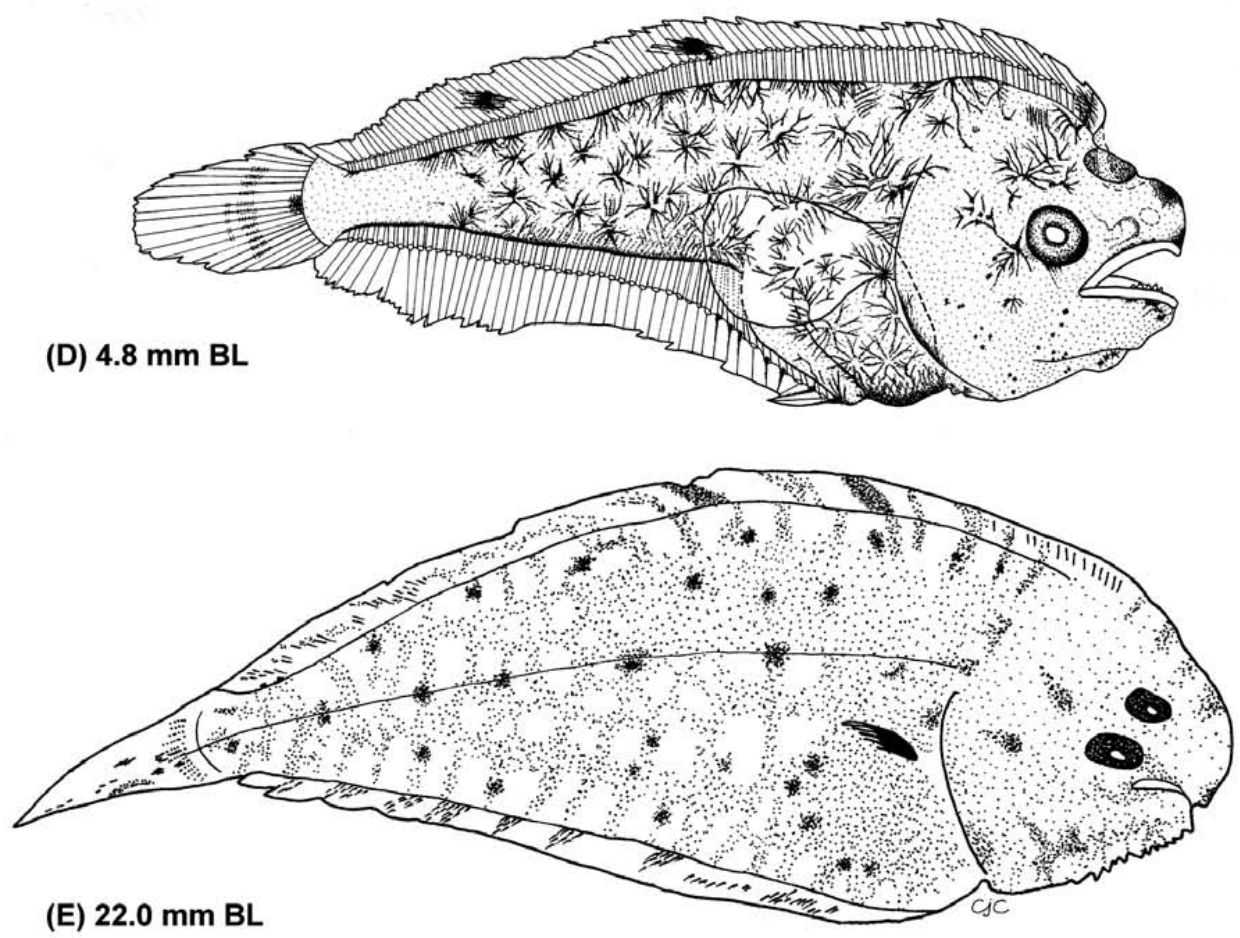

Fig. 2. - Early developmental stages of wild-caught Solea turbynei: A, preflexion; B, flexion; C, postflexion; D, metamorphosis; and E, juvenile. 
Table 2. - A list of described Pleuronectiformes larvae occurring in the Atlantic and Indian oceans off southern Africa, adapted from Wood (2000) and Thompson et al. (2007).

\begin{tabular}{|c|c|c|c|c|c|}
\hline Species & $\begin{array}{l}\text { Myomere range at } \\
\text { preflexion and flexion }\end{array}$ & Vertebrae & $\begin{array}{c}\text { Size at } \\
\text { flexion }(\mathrm{mm})\end{array}$ & Pigmentation & Reference \\
\hline Austroglossus microlepis & $56-58$ & $55-57$ & $5.2-5.5$ & $\begin{array}{l}\text { Dorsal and ventral midline; gut; lower } \\
\text { jaw; behind eyes; pectoral fins. }\end{array}$ & $\begin{array}{l}\text { O'Toole 1977, } \\
\text { Brownell } 1979\end{array}$ \\
\hline Austroglossus pectoralis & $50-58(8-10+40-49)$ & 58 & $3.5-3.8$ & $\begin{array}{l}\text { Dorsal and ventral midline; fore- and } \\
\text { hindbrain; snout; lower jaw; ventral and } \\
\text { lateral gut; small spots on finfold. }\end{array}$ & Wood 2000 \\
\hline Dagetichthys marginatus & 40 (preflexion) & 42 & $5.0-7.6$ & $\begin{array}{l}\text { Three distinct clusters on the dorsal and } \\
\text { one on the ventral finfold and later on } \\
\text { fins, when the last dorsal and ventral } \\
\text { cluster fuses to form a band over the } \\
\text { body. }\end{array}$ & Thompson et al. 2007 \\
\hline Dicologlossa cuneata & $44-47(9+35-38)$ & $43-45$ & $6.3-6.5$ & $\begin{array}{l}\text { Dorsal and ventral midline; hindbrain; } \\
\text { finfold; swim bladder; gut; head. }\end{array}$ & $\begin{array}{l}\text { Lagardère and } \\
\text { Aboussouan } 1981\end{array}$ \\
\hline Heteromycteris capensis & $39-41(10+29-31)$ & $40-43$ & 6.2 & $\begin{array}{l}\text { Midline body contour; finfold; ventral } \\
\text { gut wall; lower jaw, behind eyes; lower } \\
\text { pectoral fin margin. }\end{array}$ & Brownell 1979 \\
\hline Monochirus luteus & $36-38$ & $36-40$ & 5.5 & $\begin{array}{l}\text { Dorsal and ventral midline; midbrain; } \\
\text { posterior tail (early); finfold; ventral } \\
\text { abdominal wall. }\end{array}$ & $\begin{array}{l}\text { Nichols } 1976 \text { in Olivar } \\
\text { and Fortuño } 1991\end{array}$ \\
\hline Monochirus ocellatus & $34-37(8-9+26-28)$ & $37-38$ & 4 & $\begin{array}{l}\text { Three dorsal and two ventral concentra- } \\
\text { tions of small spots on finfold; caudal } \\
\text { tip; dorsal and ventral body contour; } \\
\text { head, lower jaw; gut wall; swim bladder; } \\
\text { pectoral fins. }\end{array}$ & $\begin{array}{l}\text { Palomera and Rubies } \\
1971 \text { in Olivar and } \\
\text { Fortuño } 1991\end{array}$ \\
\hline Pegusa lascaris & $47(9+38)$ & $42-47$ & 5.3 & $\begin{array}{l}\text { Many small melanophores scattered over } \\
\text { head, body and fins. Heaviest concentra- } \\
\text { tions over lateral and ventral gut surface } \\
\text { and laterally on the tail. }\end{array}$ & $\begin{array}{l}\text { Clarke } 1914 \text { in } \\
\text { Ahlstrom et al. } 1984, \\
\text { Russell } 1976\end{array}$ \\
\hline Solea turbynei & $32(9-10+22-24)$ & $32-34$ & $3-4$ & $\begin{array}{l}\text { Three melanophore blotches on finfold, } \\
\text { one blotch on caudal fin base, stellate } \\
\text { melanophores scattered over trunk, gut } \\
\text { and operculum. }\end{array}$ & This study \\
\hline Synapturichthys kleini & $42-45(9-10+33-35)$ & $46-47$ & 6.5 & $\begin{array}{c}\text { Densely packed stellate melanophores } \\
\text { scattered over all body surfaces and } \\
\text { finfold. }\end{array}$ & Brownell 1979 \\
\hline
\end{tabular}

\section{Pigmentation}

The general pigmentation characteristics remain similar throughout early larval development. The preflexion to postflexion stages are lightly pigmented. In the preflexion stage (3.0 $\mathrm{mm} \mathrm{BL}$ ), larvae have discrete external stellate melanophores along the dorsal and ventral margin, on the gut and operculum. A distinctive characteristic for this species is the presence of two melanophores on the dorsal finfold ( $<3 \mathrm{~mm} \mathrm{BL}$ ) that become blotches on the dorsal fin rays by $4.8 \mathrm{~mm}$ BL. These are located midway and two thirds, respectively, along the dorsal fin from the posterior head hump (Fig. 2A-E). In all larval stages there is internal pigmentation on the forebrain situated posterior to the two dorsal humps on the head. One to two stellate melanophores occur above the eye in preflexion larvae and persist with development to the settlement stage (Fig. 2A-D). Pigmentation on the tip of the upper jaw can be seen in all developmental stages, becoming more pronounced in the settlement stage (Fig. 2D). Numerous minute stellate melanophores occur on and around the gas bladder, becoming more numerous with development. The presence of a melanophore series along the dorsal and anal fin pterygiophore bases as well as randomly dispersed stellate melanophores along the trunk is evident from preflexion larvae and becomes more pronounced through development to the settlement stage (Fig. 2D), after which the larvae become heavily pigmented. A single melanophore is noticeable at the midpoint of the caudal peduncle at the base of the caudal fin by $4.3 \mathrm{~mm} \mathrm{BL}$ and persists through to the juvenile stage (Table 2). In juveniles, the ocular pectoral fin is dark in colour and is an obvious identification criterion (22.8 mm BL).

\section{Larval ecology}

\section{Temporal occurrence}

Larval S. turbynei were recorded in the nearshore, surf zone and estuarine habitats sampled in Algoa Bay (Fig. 1 ). The density of $S$. turbynei in plankton tows varied significantly among seasons in the nearshore of Algoa Bay between 5 and $30 \mathrm{~m}$ depths $\left(\mathrm{H}_{(3,210)}=49.58, \mathrm{P}<0.05\right)$, with a notable increase in larval occurrence in the summer season (Table 3). Mean larval size in summer was $2.3( \pm 0.7) \mathrm{mm}$ BL, followed by means sizes of $2.4 \pm 0.7$ $\mathrm{mm}$ BL (autumn), $2.0 \pm 0.6 \mathrm{~mm}$ BL (winter) and $2.8 \pm 0.6$ $\mathrm{mm}$ BL (spring). Similarly, abundance in the surf zone from larval seine net catches was also higher in summer $\left(\mathrm{H}_{(3,160)}=13.47, \mathrm{P}<0.05\right)$ (Table 3). Mean larval size in summer in the surf zone was $5.0( \pm 1.4) \mathrm{mm} \mathrm{BL}$, followed by means sizes of $4.5 \pm 1.2 \mathrm{~mm} \mathrm{BL}$ (autumn), 10.8 \pm 8.5 $\mathrm{mm} \mathrm{BL}$ (winter) and $6.3 \pm 1.17 \mathrm{~mm} \mathrm{BL}$ (spring). There was no noticeable peak in the larval and juvenile abundance in the mouth regions of the two bay estuaries in the fyke net catches (Table 3). Mean larval size in summer was $4.3( \pm 0.31) \mathrm{mm}$ BL, followed by mean fish sizes of 24.0 $\pm 33.9 \mathrm{~mm} \mathrm{BL}$ (autumn), 20.5 $\pm 0.5 \mathrm{~mm} \mathrm{BL}$ (winter) and a single specimen of $24.4 \mathrm{~mm}$ BL in spring. 
Table 3. - Seasonal occurrence of early developmental stages of Solea turbynei in the nearshore (2005-2007 and 2010-2012), surf zone (20102012) and estuaries (2010-2012). Values represent the mean and range in parentheses.

\begin{tabular}{|c|c|c|c|c|}
\hline & Winter & Spring & Summer & Autumn \\
\hline Nearshore (larvae/100 m³) & $0.07(0-1.59)$ & $0.08(0-1.10)$ & $1.38(0-9.52)$ & $0.29(0-3.17)$ \\
\hline Surf zone (CPUE) & $0.03(0-0.33)$ & $0.16(0-1.33)$ & $0.53(0-8.67)$ & $0.34(0-3.00)$ \\
\hline Estuaries (CPUE) & $0.02(0-1.00)$ & $0.01(0-1.00)$ & $0.07(0-5.00)$ & $0.02(0-3.00)$ \\
\hline
\end{tabular}

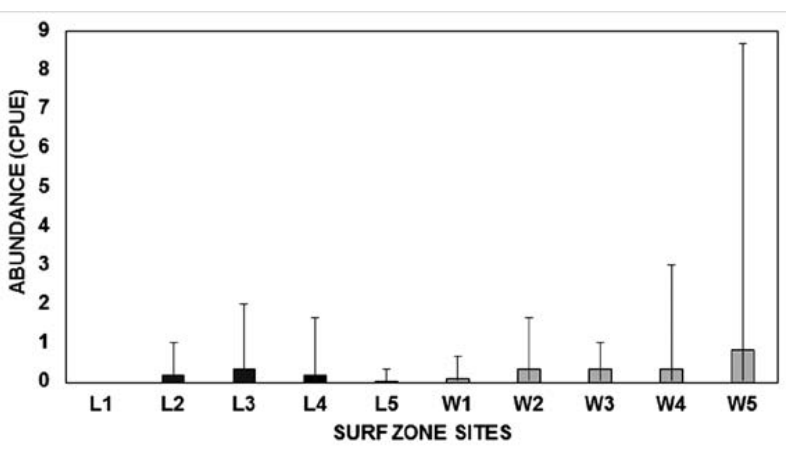

Fig. 3. - Solea turbynei occurrence at leeward and windward sites along the Algoa Bay coastline, South Africa (leeward sites L1-5 and windward sites W1-5 are shown in Fig. 1).

\section{Spatial occurrence}

At the nearshore sites (N1-N6) at the 30-m depth contour there was no significant difference in larval abundances along the length of the bay $\left(\mathrm{H}_{(5,144)}=5.43\right.$, $\mathrm{P}>0.05)$. However, in the surf zone, larval abundances were significantly different between the leeward and windward sites (Fig. 3) along the length of the bay $\left(\mathrm{U}_{(2,160)}=2690.5, \mathrm{P}<0.05\right)$. Mean surf zone abundance of 6.2 (CPUE range, 1.3-13.3) was significantly higher at the windward sites of Algoa Bay compared with the

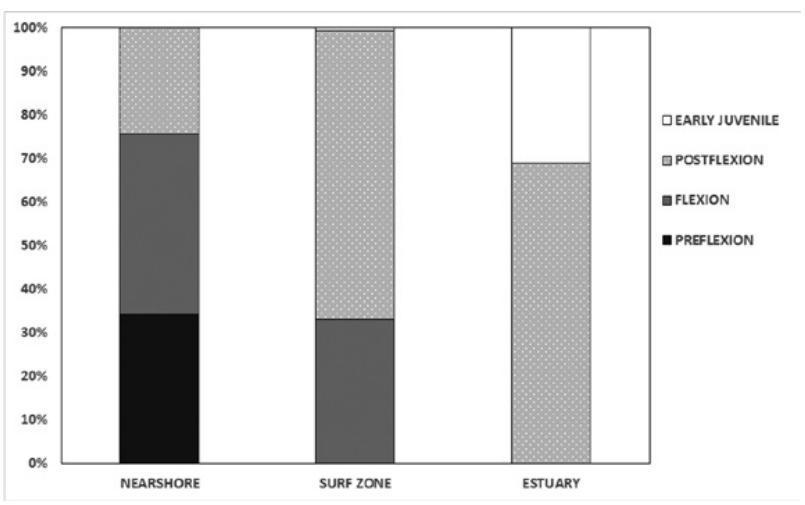

Fig. 4. - Habitat partitioning by early developmental stages of Solea turbynei in Algoa Bay, South Africa. mean CPUE of 2.27 (range, 0-5.33) at leeward sites (Fig. 3). Data for estuarine catches were too few for analysis.

Larval fish size varied among habitat samples. In the nearshore samples, mean larval size was 2.7 $( \pm 1.12) \mathrm{mm} B L$, ranging from newly hatched larvae at 1.2 to $7.8 \mathrm{~mm}$. Slightly larger larvae were found in the surf zone with a mean size of $5.9( \pm 3.6) \mathrm{mm} \mathrm{BL}$, ranging from 1.8 to $43.5 \mathrm{~mm} \mathrm{BL}$. Fish entering the estuaries had a mean size of $12.3( \pm 15.6) \mathrm{mm} B L$, ranging from 3.6 to $61.3 \mathrm{~mm}$ BL. The ontogenetic migration of larvae shoreward is clearly reflected in the developmental stages collected across the habitats sampled (Table 4, Fig. 4).

\section{Environmental drivers}

In the nearshore there was a weak relationship between temperature, salinity and turbidity and larval densities $\left(\mathrm{R}^{2}\right.$ adj $\left.=0.099 ; \mathrm{R}=0.33 ; \mathrm{P}<0.05\right)$. Temperature was the most significant factor contributing to the relationship. This trend also existed in the surf zone $\left(\mathrm{R}^{2}\right.$ adj=0.041; $\left.\mathrm{R}=0.24 ; \mathrm{P}<0.05\right)$. In the estuaries, $S$. turbynei seem to be significantly influenced by turbidity $(\mathrm{P}<0.05)$.

\section{DISCUSSION}

Solea turbynei can be identified as a Soleidae species due to the moderately pigmented, moderate body shape in early developmental stages; the absence of fin spines or extremely long dorsal fin rays in postflexion stages and the movement of the eye from the left side to the right side during metamorphosis. When compared with other South African soleid species, the lower myomere count of $S$. turbynei distinguishes this species from other common coastal inshore Pleuronectiformes in this warm temperate region (Table 2). The appearance of a deep notch forming on the top of the snout during the postflexion stage seems to be a characteristic of some soleids, after which the left eye migrates through this notch during the settlement stage (Thompson et al. 2007). The larvae are moderately pigmented (Wood 2000, Thompson et al. 2007) and become heavily pig-

Table 4. - Review of the occurrence of various body lengths of $S$. turbynei larvae in temperate coastal habitats.

\begin{tabular}{|c|c|c|c|c|}
\hline Habitats & & Larval size class $(\mathrm{mm})$ & & References \\
\hline & $<3$ & $3-4$ & $4-7$ & \\
\hline \multirow[t]{2}{*}{ Nearshore } & $\mathrm{X}$ & $\mathrm{X}$ & & This study \\
\hline & & $\mathrm{X}$ & & Pattrick and Strydom 2008 \\
\hline \multirow[t]{3}{*}{ Surf zone } & $\mathrm{X}$ & $\mathrm{X}$ & $\mathrm{X}$ & Beckley 1986 \\
\hline & $\mathrm{X}$ & $\mathrm{X}$ & & Watt-Pringle and Strydom 2003 \\
\hline & & & $\mathrm{X}$ & Strydom 2003a \\
\hline \multirow{2}{*}{ Estuarine } & & $\mathrm{X}$ & & Montoya-Maya and Strydom 2009 \\
\hline & & & $\begin{array}{l}X \\
X\end{array}$ & $\begin{array}{l}\text { Melville-Smith and Baird } 1980 \\
\text { Strydom et al. } 2003\end{array}$ \\
\hline
\end{tabular}


mented only at the settlement stage. The larval stages of Austroglossus pectoralis and the often sympatric Heteromycteris capensis show some resemblance to $S$. turbynei as they have similar pigmentation characteristics in the preflexion to early postflexion stages. However, $S$. turbynei becomes more heavily pigmented in the settlement stage than the other two species (Thompson et al. 2007). Austroglossus pectoralis has a similar size to $S$. turbynei at flexion but all three aforementioned species have dissimilar myomere/vertebral counts, with $A$. pectoralis and $H$. capensis having much higher counts than S. turbynei (Wood 2000).

Juvenile $S$. turbynei are distinctive from other Soleidae as they have a very small, heavily pigmented pectoral fin on the ocular side (Smith and Heemstra 1995). Synapturichtys kleini have a similar pectoral fin shape and ray count (Smith and Heemstra 1995). However, the dorsal and anal fins of Solea turbynei are connected to the caudal peduncle by a basal membrane, which is not the case for S. kleini (Smith and Heemstra 1995). Monochirus luteus and M. ocellatus have a similar basal membrane and have similar pigmentation characteristics to $S$. turbynei, but their blind side pectoral fin is rudimentary and their range is from Namibia northwards (Smith and Heemstra 1995).

Based on the occurrence of newly hatched and preflexion stage larvae in the nearshore during this study, Solea turbynei appears to be spawning predominantly in the ocean despite some speculation in the literature on isolated estuarine spawning events in South Africa (Wallace 1975, Cyrus 1991, Kruger and Strydom 2010). Larval abundance peaks in summer in the nearshore and surf zone habitats of Algoa Bay, coinciding with spring to summer spawning of many coastal fish species and the highest food availability for young fishes (Beckley 1986, Whitfield 1998). Pattrick and Strydom (2008) recorded significantly larger BLs of larvae of marine estuarine-opportunist and marine estuarine-dependent species closer to shore, including S. turbynei. This finding supports the proposal of spawning and hatching in the nearshore environment and a general shoreward movement towards surf zone habitats with ontogeny. Solea turbynei larvae also use surf zones as an alternative nursery area for the juveniles (Whitfield 1989). It has been proposed that postflexion larvae and juveniles can spend a considerable amount of time in surf zones before recruitment into estuaries (Potter et al. 1990, Strydom 2003a). The surf zone represents a homogenous environment when compared with estuaries (Whitfield 1989). The welloxygenated environment has a uniform salinity and affords opportunities for shelter in wave-cut depressions and old rip current channels despite the high wave energy (Watt-Pringle and Strydom 2003). The surf zone environment in Algoa Bay provides a large amount of food in the form of the mysid, Mesopodopsis slabberi, surf diatoms, copepods, and crustacean larvae (Lasiak 1981, Whitfield 1989, Campbell and Bate 1991). Many fishes then migrate into estuaries due to changes in dietary requirements, increased need for shelter and rich food resources (Lasiak 1981, Whitfield 1998). Recruitment into estuaries begins in the postflexion larval stage for many marine estuarine-opportunist and marine estuarine-dependent species in temperate South Africa (Strydom 2014). Postflexion S. turbynei larvae are found in permanently open estuaries on the warm temperate coast of South Africa typically at a mean of $7.9 \mathrm{~mm}$ BL (range 4.1-14.8 mm BL) (Strydom et al. 2003a). High turbidity plumes emerging from rivers and estuaries are known to produce a cueing response in postflexion larvae, as was observed off the mouth of the Van Stadens and Kabeljous estuaries after localized flooding. The significantly higher abundance of $S$. turbynei larvae on the windward side on Algoa Bay also indicates that the distribution of postflexion larvae may be influenced by the prevailing oceanography of the region. However, it is known that larval fishes have significant sensory and mobility capabilities and are able to alter their spatial and temporal position to increase their chances of survival (Watt-Pringle and Strydom 2003). The high abundance of surf diatoms on the windward side of the bay may serve as an important dietary component for settlement stages. However, this hypothesis requires further investigation as few studies have focused on wild larval fish diet in southern African waters.

The higher prevalence of juvenile $S$. turbynei in autumn in estuaries corresponds to the summer recruitment of postflexion and settlement stage larvae into estuarine nurseries from the nearshore of Algoa Bay. Similarly, S. turbynei also recruited into a subtropical South African estuary at similar sizes ranging from 5 to $15 \mathrm{~mm}$ BL (Cyrus and Martin 1991). Van Schie and de Boer (2003) expanded the understanding of recruitment dynamics of this species and proposed two different estuarine recruitment periods on the subtropical coast of South Africa: (1) from the breeding stock spawning within estuaries in summer, resulting in the presence of larval stage $S$. turbynei in the estuary; and (2) the offshore juvenile stock recruiting back into the estuary in winter.

In the nearshore and surf zone habitats, larval occurrence was significantly linked to temperature and this finding is probably linked to the effects of adult spawning patterns in the region and higher larval survival with higher summer secondary productivity. Salinity changes (Pattrick and Strydom 2008) and other as yet unidentified cues (Strydom 2003a) are also known to influence larval occurrence in the nearshore and surf zones closer to the mouths of estuaries. Adults tend to have a strong affinity to muddy substrates and higher turbidity (Potter et al. 1990, Cyrus 1991). This finding is supported by those of this study, as turbidity was a significant factor affecting recruitment dynamics of older developmental stages of $S$. turbynei in the bay estuaries. Estuaries play a pivotal role as nurseries for larval and juvenile fishes in South Africa, providing higher temperatures for faster growth, greater food supply and, calmer, sheltered areas with increased protection from predators (Wallace et. al. 1984, Strydom 2003b, Strydom 2014).

This species exhibits a complex early life history strategy spanning the nearshore, surf zones and estuarine habitats, which is underpinned by environmental 
drivers such as food availably, shelter and physicochemical and/or settlement cues. Nursery habitat partitioning with ontogeny provides an important selective advantage, reducing competition with other species and enabling Solea turbynei to successfully access and colonize estuaries along the South African coast.

Larval fish descriptions are a prerequisite for identifying the early developmental stages of fishes in order to fully understand the complexities of fish populations worldwide. Fish descriptions are therefore a fundamental scientific tool for ichthyology (Strydom and Neira 2006). However, larval descriptions spanning the entire developmental series are lacking for many coastal fish species in South Africa. Much effort is needed in this research field in order to fully complement the understanding of fish populations and their conservation in South Africa.

\section{ACKNOWLEDGEMENTS}

The National Research Foundation of South Africa is thanked for providing funding to support this research (Grant number 79733, N.A. Strydom). Water quality instrumentation was provided through a grant from the International Foundation for Science. Numerous field workers are thanked for their field assistance.

\section{REFERENCES}

Ahlstrom E.H., Amaoka K., Hensley D.A., et al. 1984. Pleuronectiformes: Development. In: Moser H.G., Richards W.J., Cohen D.M., et al. (eds), Ontogeny and Systematics of Fishes. Am. Soc. Ichthyol. Herpetol., Spec. Publ., 1: 565-573.

Beckley L.E. 1986. The Ichthyoplankton assemblage of the Algoa Bay nearshore region in relation to coastal zone utilization by juvenile fish. S. Afr. J. Zool. 21: 244-252.

Brownell C.L. 1979. Stages in the early development of 40 marine fish species with pelagic eggs from the Cape of Good Hope. Ichthyol. Bull. J.L.B. Smith Inst. Ichthyol. 40: 1-84.

Campbell E.E., Bate G.C. 1991. Ground water in the Alexandria dune field and its potential influence on the adjacent surf-zone. Water SA. 17(2): 155-160.

Cyrus D.P. 1991. The reproductive biology of Solea bleekeri (Teleostei) in Lake St. Lucia on the south-east coast of Africa. S. Afr. J. Mar. Sci. 10: 45-51. http://dx.doi.org/10.2989/02577619109504618

Cyrus D.P., Blaber S.J.M. 1987. The influence of turbidity on juvenile marine fishes in estuaries. Part 1 Field studies at Lake St. Lucia on the southeastern coast of Africa. J. Exp. Mar. Biol. Ecol. 109: 53-70. http://dx.doi.org/10.1016/0022-0981(87)90185-7

Cyrus D.P. Martin T.J. 1991. The importance of estuaries in life histories of flatfish species on the southern coast of Africa. Neth. J. Sea Res. 27(3-4): 255-260. http://dx.doi.org/10.1016/0077-7579(91)90028-Y

Goschen W.S., Schumann E.H. 1994. An Agulhas Current intrusion into Algoa Bay during August 1988. S. Afr. J. Mar. Sci. 14: 47-57. http//dx.doi.org/10.2989/025776194784286914

Goschen W.S., Schumann E.H. 1995. Upwelling and the occurrence of cold water around Cape Recife, South Africa. S. Afr. J. Mar. Sci. 16: 57-67. http://dx.doi.org/10.2989/025776195784156520

Goschen W.S., Schumann E.H. 2011. The physical oceanographic processes of Algoa Bay, with emphasis on the western coastal region. South African Environmental Observation Network (SAEON) and the Institute of Maritime Technology (IMT). IMT document number: PO106-10000-730002. 85 pp.

Heemstra P.C., Heemstra E. 2004. Coastal Fishes of Southern Africa. South African Institute for Aquatic Biodiversity and the National Inquiry Service Centre. 488 pp.

Kruger M., Strydom N.A. 2010. Spatial and temporal variability in the larval fish assemblage of a warm temperate South African estuary, with notes on the effects of artificial channelling. Afr. Zool. 45(2): 195-212.

http://dx.doi.org/10.3377/004.045.0221

Lagardère F., Aboussouan A. 1981. Développement du céteau, Dicologoglossa cuneata (Moreau, 1881) (Pisces, Pleuronectiformes, Soleidae): II. - Description des larves, Cybium, 5(2): 53-72.

Lasiak T.A. 1981. Nursery grounds of juvenile teleosts: evidence from the surf zone of King's Beach, Port Elizabeth. S. Afr. J. Sci. 77: 388-390.

Melville-Smith R., Baird D. 1980. Abundance, distribution and species composition of fish larvae in the Swartkops estuary. S. Afr. J. Zool. 15: 72-78.

Montoya-Maya P.H., Strydom N.A. 2009. Description of larval fish composition, abundance and distribution in nine south and west coast estuaries of South Africa. Afr. Zool. 44: 75-92. http://dx.doi.org/10.3377/004.044.0108

Neira F.J., Miskiewicz A.G., Trnski T. 1998. Larvae of Temperate Australian Fishes. Laboratory Guide for Larval Fish Identification. University of Western Australia Press, Nedlands, 474 pp.

Nelson J.S. 2006. Fishes of the World. John Wiley and Sons, Inc. $624 \mathrm{pp}$.

Olivar M.P., Fortuño J.M. 1991. Guide to ichthyoplankton of the southeast Atlantic (Benguela Current Region). Sci. Mar. 55(Suppl. 1): 1-383.

O’Toole M.J. 1977. Development and distributional ecology of the larvae of the West Coast Sole Austroglossus microlepis. Fish. Bull. S. Afr. 9: 32-45.

Pattrick P., Strydom N.A. 2008. Composition, distribution and seasonality of larval fishes in the shallow nearshore of the proposed Greater Addo Marine Reserve, Algoa Bay, South Africa. Estuar. Coast. Shelf Sci. 79: 251-261. http://dx.doi.org/10.1016/j.ecss.2008.04.009

Pattrick P., Strydom N.A. 2014a. The effects of exposure in sandy beach surf zones on the early life history stages of fishes within Algoa Bay, South Africa. J. Fish Biol. 84: 1354-1376. http://dx.doi.org/10.1111/jfb.12360

Pattrick P., Strydom N.A. 2014b. Larval fish variability in response to oceanographic features in a nearshore nursery area. J. Fish Biol. 85: 857-881 http://dx.doi.org/10.1111/jfb.12477

Pattrick P., Strydom N.A., Goschen W.S. 2013. Shallow-water, nearshore current dynamics in Algoa Bay, South Africa, with notes on the implications for larval dispersal. S. Afr. J. Mar. Sci. 35(2): 269-282. http://dx.doi.org/10.2989/1814232X.2013.798593

Potter I.C., Beckley L.E., Whitfield A.K., et al 1990. Comparisons between the roles played by estuaries in the life cycles of fishes in temperate Western Australia and southern Africa. Environ. Biol. Fishes 28: 143-178. http://dx.doi.org/10.1007/BF00751033

Potter I.C., Tweedley J.R., Elliott M., et al. 2013. The ways in which fish use estuaries: a refinement and expansion of the guild approach. Fish and Fisheries 16: 230-239. http://dx.doi.org/10.1111/faf.12050

Richardson N., Whitfield A.K., Paterson A.W. 2006. The influence of selected environmental parameters on the distribution of the dominant demersal fishes in the Kariega Estuary channel, South Africa. Afr. Zool. 41: 89-102. http://dx.doi.org/10.3377/1562-7020(2006)41[89:TIOSEP] 2.0.CO;2

Russell F.S. 1976. The Eggs and Planktonic Stages of British Marine Fishes. Academic Press, London.

Schumann E.H., Churchill J.R.S., Zaayman H.J. 2005. Oceanic variability in the western sector of Algoa Bay, South Africa. S. Afr. J. Mar. Sci. 27: 65-80. http://dx.doi.org/10.2989/18142320509504069

Smith M.M., Heemstra P.C. 1995. Smiths' Sea Fishes. Southern Book Publishers (Pty) Ltd, Johannesburg, xx + 1047 pp.

Strydom N.A. 2003a. Occurrence of larval and early juvenile fishes in the surf zone adjacent to two intermittently open estuaries, South Africa. Environ. Biol. Fishes 66: 349-359. http://dx.doi.org/10.1023/A:1023949607821

Strydom N.A. 2003b. An assessment of habitat use by larval fishes in a warm temperate estuarine creek using light traps. Estuar. 26(5): 1310-1318. http://dx.doi.org/10.1007/BF02803633

Strydom N.A. 2014. A review of larval fish occurrence in temperate South African estuaries with particular emphasis on estuary type and freshwater inflow. Estuar. Coasts 38: 268-284. 
http://dx.doi.org/10.1007/s12237-014-9801-x

Strydom N.A., Neira F.J. 2006. Development and ecology of the larvae of Glossogobius callidus and Redigobius dewaali (Teleostei: Gobiidae) from temperate South African estuaries. Afr, Zool. 41(2): 240-251.

http://dx.doi.org/10.3377/1562-7020(2006)41[240:DAEOLO] 2.0. $\mathrm{CO} ; 2$

Strydom N.A., Whitfield A.K., Wooldridge T.H. 2003. The role of estuarine type in characterizing early stage fish assemblages in warm temperate estuaries, South Africa. Afr. Zool. 38(1): 29-43.

Thompson E.F., Strydom N.A., Hecht T. 2007. Larval development of Dagetichthys marginatus (Soleidae) obtained from hormoneinduced spawning under artificial conditions. Sci. Mar. 71(3): 421-428.

Vachon J., Desoutter M., Chapleau F. 2005. Solea bleekeri Boulenger, 1898, a junior synonym of Pegusa nasuta (Pallas 1814), with the recognition and redescription of Solea turbynei Gilchrist, 1904 (Pleuronectiformes: Soleidae). Cybium 29(4): 315-319.

Van Schie A.M.P., De Boer W.F. 2003. Population dynamics and spawning of the flatfish Solea bleekeri and Pseudorhombus arsius in the intertidal area of Inhaca island, Mozambique. S. Afr.
J. Mar. Sci. 25: 49-60. http://dx.doi.org/10.2989/18142320309504000

Wallace J.H. 1975. The estuarine fishes of the east coast of South Africa. 3. Reproduction. The Oceanographic Research Institute South Africa, Durban (No. 41). 51 pp.

Wallace J.H., Kok H.M., Beckley L.E., et al. 1984. South African estuaries and their importance to fishes. S. Afr. J. Sci. 80: 203-207.

Watt-Pringle P.W., Strydom N.A. 2003. Habitat use by larval fishes in a temperate South African surf zone. Estuar. Coast. Shelf Sci. 58: 765-774. http://dx.doi.org/10.1016/S0272-7714(03)00183-5

Whitfield A.K. 1989. Ichthyoplankton in a southern African surf zone: nursery area for the postlarvae of estuarine associated fish species? Est. Coast. Shelf Sci. 29: 533-547. http://dx.doi.org/10.1016/0272-7714(89)90009-7

Whitfield A.K. 1998. Biology and Ecology of Fishes in South African Estuaries. Ichthyol. Monogr. J.L.B Smith Inst. Ichthyol., No. 2, 223 pp.

Wood A.D. 2000. The description of Austroglossus pectoralis (Teleostei: Soleidae) larvae from the south-east coast of South Africa. Sci. Mar. 64(4): 387-392. 